\title{
Multicultural heritage as a basis for sustainable development of urban tourism in Warsaw - COVID-19 pandemic time
}

\author{
Anna Ostrowska-Tryzno, \\ Anna Pawlikowska-Piechotka
}

\begin{abstract}
Introduction: The importance of multiculturalism for the development of tourism, consistently emphasized in the literature, shows the long history and rich tradition of this form of tourism. Poland has historically been a land of transition between East and West, a land where different cultures have existed side by side: German, Jewish, Polish, and Russian. For centuries Poland was a meeting place of different religions and cultures and today's landscape still shows evidence of this. The catastrophe of World War II brought the annihilation of a multicultural society and created a homogeneity, unprecedented in our history.

Jewish heritage and urban cultural tourism: In their almost 2000-year diaspora, Jews have been present in Poland for eight hundred years: from the early middle ages until the Holocaust, the annihilation during World War II. The Jews were distinguished from other community groups by their religion, language, customs, art and architecture. In the interwar period of the $20^{\text {th }}$ century, Poland was home to the largest Jewish community in Europe, distinguished by its enormous cultural and intellectual vitality.

Pandemic time: The outbreak of the COVID-19 pandemic has hit the tourism sector hard, and travel restrictions still apply to us. Therefore, it is necessary to verify the forecasts and prepare new recommendations for cultural tourism destinations during and after the pandemic.

Conclusions: Recently there has been a revival of interests in Jewish heritage and many tourists (both domestic and foreign) want to explore Jewish culture and remaining monuments of the past. Despite pandemic time restrictions it is also possible, however new actions and policy are required to secure sanitary recommendations and rebuild consumer confidence.
\end{abstract}

Key words: multicultural heritage, urban tourism, COVID-19 pandemic time

\section{Introduction}

The recognition of cultural tourism within academic literature shows the long history and rich tradition of this form of tourism. Throughout the centuries, urban tourism has grown significantly: from visiting holy places, spas in the ancient civilizations, pilgrimages across medieval Europe, urban tourism (Paris, Rome, Florence and Venice) enjoyed within the European Grand Tour in the seventeenth and eighteenth centuries, re-discovery of spas in the eighteenth and nineteenth centuries, world exhibitions and sports events in the late nineteenth and early twentieth century [Law 1996; Williams 2003]. The global wealth of traditions, history, culture and diversity are the strong motivations for contemporary travellers. 
Nowadays, tourism to host communities is motivated (wholly or partly) by interest in history, heritage and everyday lifestyle. In recent decades, we have been able to observe the development of different forms of urban tourism. Therefore the term of cultural heritage tourism could be interpreted in many ways [Dallen, Boyd 2003; EESC 2005a; EESC 2005b; Hall 2000; Inskeep 1991; Loyke, Edmunds 2007; Sigala, Leslie 2006; Smith 2006; UNWTO 2005]. Nevertheless, the main motivation of visitors is curiosity and education, interest in other people and their culture.

Cultural tourism, what was important in context of the planned research project, was understood in the broad sense of this term as: not only 'high culture' (artefacts preserved and presented in museums), historic or heritage buildings, sites, monuments, opulent historic residences, but also non-material values: popular folklore, traditional events, music and food. Although traditional urban destinations such as Rome, London, Amsterdam, Paris, Venice, Athens, Barcelona, Lisbon Madrid and Vienna attract tourists, newer destinations are emerging. These include mainly East European locations: Budapest, Prague, Vilnius, Lvov, Cracow and Warsaw, which are today internationally considered as promising sites of culture tourism development [EECS 2005a, EECS 2005b, ECTN 2020, Law 1996; Smith 2006; Williams 2003]. In 2019 in Warsaw we experienced more than 10000000 tourist visits (accordingly to Central Statistical Office in Warsaw data, GUS 2020), inspired mainly by business, but also by interest in visiting museums and galleries, taking part in festivals and cultural displays. Almost 30\% were tourists from abroad (Germany, Ukraine, United

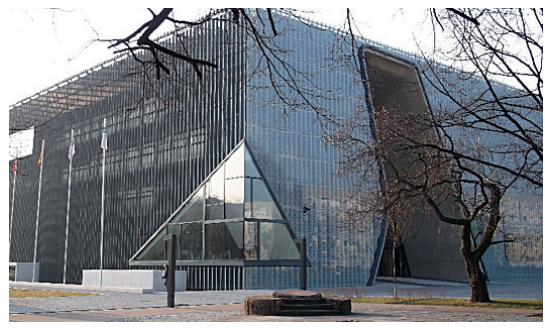

Fig. 1. Building of the Museum of the History of Polish Jews POLIN in Warsaw, view from the Ludwik Zamenhoff Street

Photo: A. Pawlikowska-Piechotka, 2019

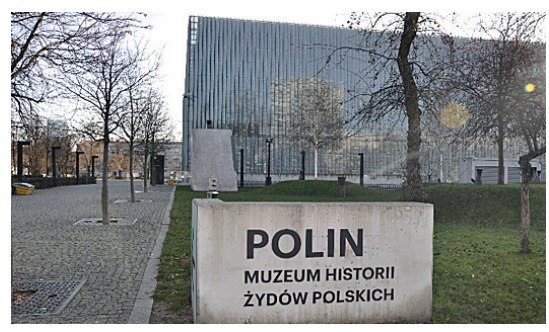

Fig. 2. Building of the Museum of the History of Polish Jews POLIN in Warsaw, view from the Józef Lewartowski Street

Photo: A. Ostrowska-Tryzno, 2020

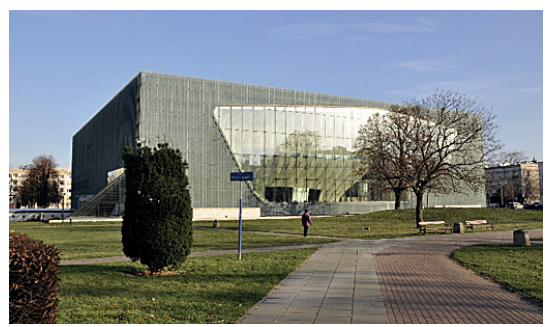

Fig. 3. Building of the Museum of the History of Polish Jews POLIN in Warsaw, view from the Karmelicka Street

Photo: A. Ostrowska-Tryzno, 2020 States and Italy) [um. warszawa.pl, 2021].

The strong inspiration for many tourists visiting Warsaw was the multicultural tradition of the site, as for example rich history, tradition and Jewish heritage - number of visitors recorded by POLIN Museum (Museum of the History of Polish Jews) was the proof of this motivation [polin.pl/en, 2021] (Figs. 1, 2, 3). 


\section{Jewish history, tradition and heritage in Warsaw}

Poland has historically been a land of transition between East and West, a land where different cultures have existed side by side: German, Jewish, Polish, and Russian. For centuries Poland was a meeting place of different religions and cultures and today's landscape is proof of this to this day. This cultural diversity is evidenced by the preserved architectural monuments: Orthodox and Catholic churches, Calvinist and Protestant chapels, synagogues and mosques, which could be found on Polish territory. The catastrophe of World War II brought the annihilation of the multicultural society and created a homogeneity unknown in our history. Just before the World War II, 3.5 million Jews lived in Poland, which constituted about $10 \%$ of the country's total population. The Holocaust took place mainly on Polish territories occupied by the Nazis and resulted in extermination of almost entire Jewish minority [Drozdowski, Sołtan, Zahorski 2017; Majewski 2019; Piechotka M., Piechotka K. 2004a; Piechotka M., Piechot-
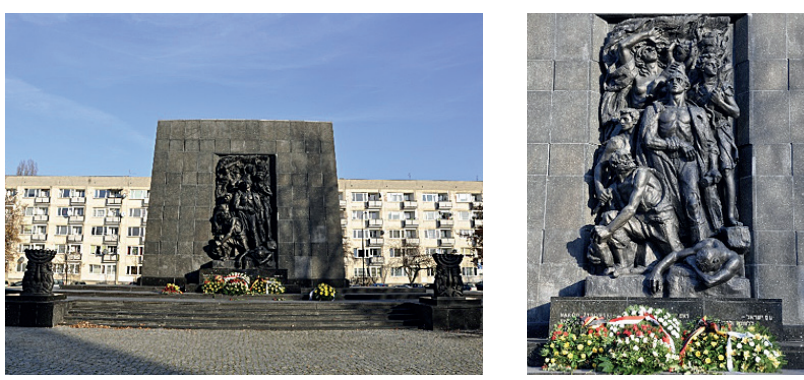

Figs. 4, 5. The Monument to the Warsaw Ghetto Heroes

Photo: A. Ostrowska-Tryzno, 2020 ka K. 2004b] (Figs. 4, 5).

The history of Jews in Warsaw is today mainly viewed from the perspective of the Holocaust, as just in a few years, between 1939 and 1943, this rich and colorful urban culture of the commune was almost completely destroyed. It mainly survived in people's memories, literary works, photographs and archival films. However, some material traces of Jewish culture have survived and remained to the present day (single architectural relics, the cemetery on Okopowa Street and Bródno Borough, the Nożyk Synagogue, fragments of the ghetto walls, remnants of pavements) and could be the foundation for cultural tourism (Figs. 6, 7, 8). Its base - are only these few material traces, which could present the culture of Jewish community/commune along with the richness of immaterial heritage, culture of everyday life and 'high culture' presented in the once-existent city that has never been rebuilt. Although it may be argued, that the Jews of Warsaw lacked the tradition and character, that was so important aspect of Jewish communities in Cracow, Lublin and Lvov - where Jews had lived for generations - it is clear, that the Jews gave Warsaw the spirit of energy, rapid progress, development and significant high culture values in the $19^{\text {th }}$ and the $20^{\text {th }}$ centuries.

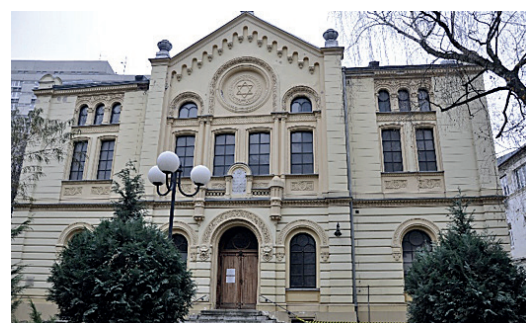

Fig. 6. Nożyk Synagogue in Warsaw, 6 Twarda Street in Warsaw

Photo: A. Ostrowska-Tryzno, 2020 


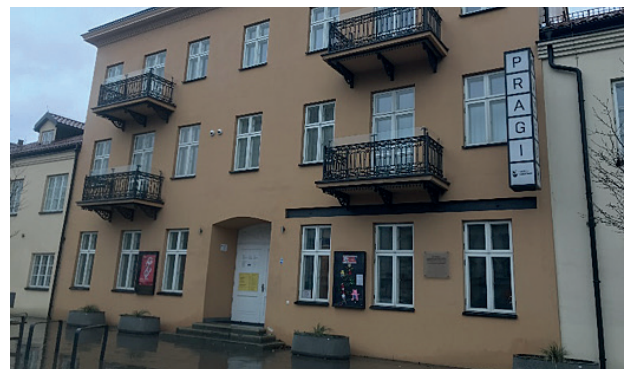

Fig. 7. Museum of Praga Borough, 50/52 Targowa Street in Warsaw

Photo: A. Ostrowska-Tryzno, 2020

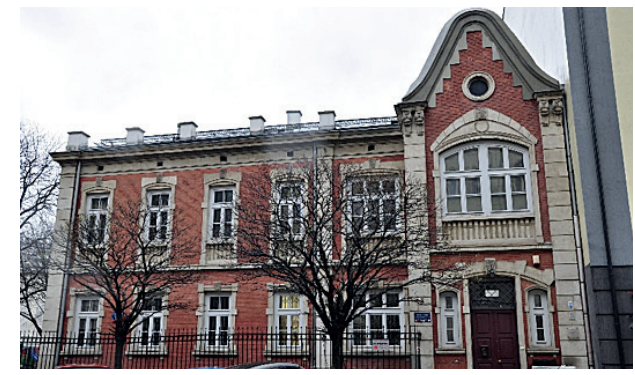

Fig. 8. The Old Jewish Bath House - Mykwa, Praga Borough, 17 Kłopotowskiego Street in Warsaw

Photo: A. Ostrowska-Tryzno, 2020

As Warsaw has been geographically and historically a town of transition between East and West, it has been a town where different cultures have existed side by side: Polish, Jewish, German and Russian. Architectural monuments of the town bear witness to this multicultural tradition. Warsaw probably more than other Polish cities was a meeting place of different religions and cultures and for example the landscape of Praga Borough still shows evidence of this: the Byzantine style Orthodox Cathedral of Saint Mary Magdalene in Warsaw, the baroque Roman Catholic Church of Our Lady of Loreto, the Jewish Synagogue at 50/52 Targowa Street. The catastrophe of World War II created a previously unknown homogeneity of Warsaw's population, but still retains the awareness of the rich multicultural past, at present so eagerly being rediscovered by young generation of Poles, Jews and other European nations.

The phenomenon of urban heritage tourism in the $21^{\text {st }}$ century has been widely recognized by researches [Dallen, Boyd 2003; Hall 2000; Smith 2006]. In most countries, the 'cultural economy' makes up significant share of GDP, five percent or more [Sigala, Leslie 2006]. Europe and Poland are no exception in this respect. Heritage tourism theory assumes that urban space generates a variety of synergetic and innovative effects relevant to both consumption and production of culture and creativity ('culture economy'). Today, in many Polish cities, we observe an increasing presence of urban creative clusters. On the example of Warsaw, Cracow and Gdansk we can see the growing importance of leisure and cultural activities. During the last three decades (1989-2019) urban tourism and especially city-based cultural tourism have become of increasing importance in Warsaw.

For this reason Faculty of Tourism and Recreation at Józef Piłsudski University of Physical Education in Warsaw (AWF) has carried the study on the urban tourism based on cultural heritage of the city (the research project was supported by the Ministry of Science and Higher Education statutory grant: DS-144). Consequently, as the main purpose was to increase our knowledge on the urban tourism in Warsaw and study the importance of the cultural heritage to the sustainable tourist development, we included Jewish heritage to the planned case studies. The main results of this part of the survey are presented in this paper. The survey on the Jewish heritage at the Praga Borough in Warsaw was also supported by the European Science Foundation (grant ESF SCH/SCSS EW 80), project 'Exploring Creative Cities: The Cultural 
And Economic Values of Cultural Industries Clusters', coordinated by Prof PhD Erik Hitters from the Erasmus University Rotterdam, Faculty of History of Arts, Rotterdam (Netherlands).

\section{Research methods and questions}

The aim of the research was to examine the phenomenon of cultural heritage as tourist attractions in Warsaw. We were interested in the comparative review of selected case studies, for example Jewish cultural relics in Warsaw, Chopin Jubilee in Warsaw - as significant magnets for urban tourism [Ostrowska-Tryzno et al. 2020].

It was planned with a hope, that our hypothesis, 'The culture heritage might became a component of economic growth, employment, innovation and social cohesion', could thus be verified.

Part of our research survey was focused on multicultural phenomenon on the example of Jewish cultural heritage in Warsaw, considered as a magnet for tourists and a chance for sustainable urban development. Surveyed and evaluated were elements of urban environment, such as: remains of multicultural relics and symbols of history and tradition, visual quality of architectural style and character, museums offer, festivals and events, as well as immaterial traces of Jewish culture. We were also interested in the local government policy of promotion Jewish heritage and the role of cultural institutions. Our intention was to examine selected architectural relics of Jewish architecture, which became a cultural tourist attraction (Nożyk Synagogue, Synagogue at Targowa Street, Jewish cemeteries, public buildings at Jagiellońska Street) - seen as a base and

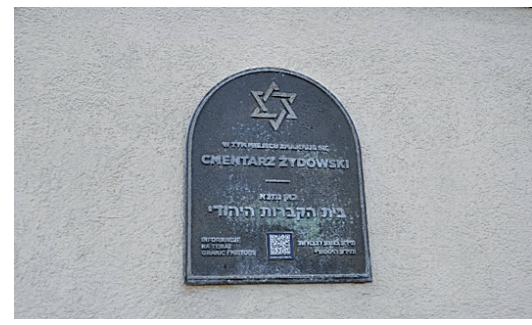

Fig. 9. The Jewish Cemetery, Okopowa Street in Warsaw

Photo: A. Ostrowska-Tryzno, 2020 potential of cultural tourism (Figs. 9, 10, 11).

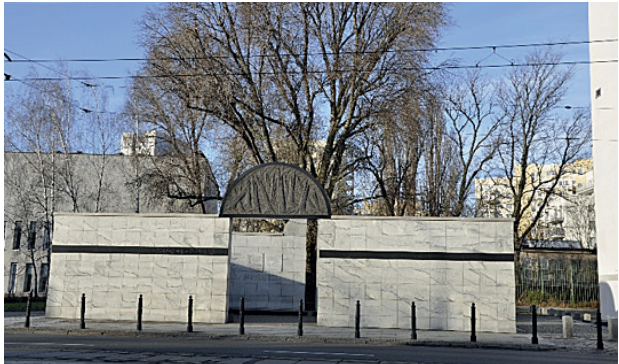

Fig. 10. Umschlagplatz - The monument symbolizing an open freight car, to commemorate the deportations of the Warsaw Ghetto victims to

Nazi death camps during the World War II, Stawki Street, Warsaw

Photo: A. Ostrowska-Tryzno, 2020

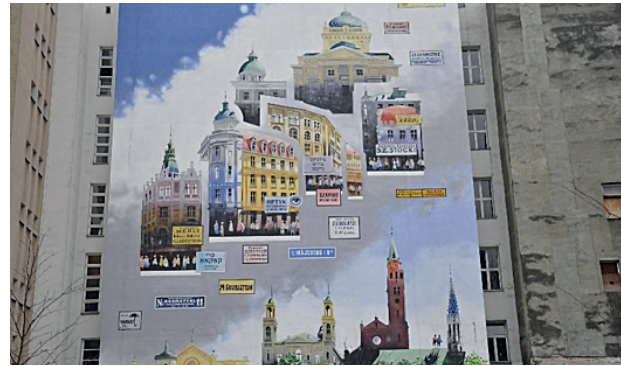

Fig. 11. The mural "Jewish Warsaw" by Tytus Brzozowski at 12 Próżna Street in Warsaw Photo: A. Ostrowska-Tryzno, 2020 
The role of culture heritage in the urban sustainable development is significant and depends on many different factors, therefore many aspects and broad research context should be considered, consequently different research tools used [Dallen, Boyd 2003; Finn, Elliott-White, Walton 2000; Hall 2000; Inskeep 1991; Law 1996; Sigala, Leslie 2006; Smith 2006, Williams 2003]. When planning our research assumptions, we deliberately moved beyond the mono-disciplinary approach, deciding on multidisciplinary analytical framework that, as we hoped, might help develop our understanding of the relationship between the cultural heritage and sustainable urban tourism development in Warsaw.

In 2020, the COVID-19 pandemic situation forced to verify most of the theoretical approaches to the planned research methods, as face - to face, in situ, interviews were not possible to be conducted. Moreover, since 2020 new approach, policy, tools have been necessary to answer the needs for tourism in the pandemic time and recommendations for cultural tourism recovery to be shaped for the post COVID-19 time (for short, medium and long term implementations).

As there was no blueprint for all stages of our research, for each segment (step) a separate framework was planned. As a consequence of the above-listed factors, the part of the design focused on the study of Jewish heritage in the context of urban sustainable tourism, consisted of five main steps:

a) A clear statement of problem, formulating the general aims and purposes, research questions and assumptions, also anticipated outcomes of planned research - were the base for selection research methods, suitable for the task and identify organization schedule for works;

b) Critical literature review on cultural tourism and the urban tourism sustainable development (including social and economic issues), books, documents and other relevant publications covering the research questions; recording data;

c) Critical review and analysis of quantitative and qualitative data from existing resources (Central Statistical Office in Warsaw, Warsaw Municipal Office, Jewish Historic Institute ŻIH, Praga Borough Museum and POLIN Museum of the History of Polish Jews), focused on the heritage tourism in Warsaw based on Jewish culture; recording data;

d) Studies conducted in Warsaw, with the use of non-structured and semi-structured interviews with the city self-government, cultural institutions (museums) and travel agencies representatives; interviews conducted on-site, face-to-face (PAPI method); participant observations, field notes and photographs (case studies: Praga Borough Museum, Nożyk Synagogue, POLIN Museum, Jewish cemeteries); survey included history of sites, its meaning for cultural tourist development and tourist offer, institutional offer and policy in promotion of Jewish heritage in Warsaw, number of tourists visiting the Jewish heritage sites in Warsaw and their characteristics; accessibility of these sites to disabled tourists; recording data.

Some parts of this stage could not be completed (due to the COVID-19 pandemic) and it was necessary to re-design our approaches, excluding interviews conducted on-site, face-toface (primary the PAPI method was planned to be used) and participant observations. 
Instead, a new approach was introduced:

a) Critical review and analysis of the quantitative and qualitative secondary data, concerning the impact of COVID-19 on cultural tourism, sanitary restrictions, law regulations and quest for the new solutions - data available in different resources (UNWTO recommendations and reports, law regulations in Poland, Warsaw Municipal Office reports, Jewish Historic Institute), as well as data collected from POLIN (the Museum of the History of Polish Jews), Praga Borough Museum, travel agencies operating in Warsaw - concerning their offers for tourists during pandemic time restrictions; recording data;

b) Analysis, evaluation and interpretation of collected and recorded data, judging the merit of case study, drawing conclusions of general character, writing a report with final findings.

\section{Jewish heritage and cultural tourism in Warsaw}

In their almost 2000-year diaspora, Jews have been present in Poland for eight hundred years: from the early middle ages until the Holocaust. The Jews were distinguished from other community groups by their religion, the language, their customs, art and architecture. Most Jews lived in small towns shtetl, in many regions forming the majority of population and creating their own communities governed accordingly to their own laws. As they had autonomy within their communities, each was governed by a group of elder's kahal, with the great support of priests - rabbi. From the $14^{\text {th }}$ century till the beginning of World War II, Poland was known as the cultural and spiritual centre of European Jews. The cultural life of the Polish Jews flourished, Talmudic scholars and numerous academies yeshiva students were highly acclaimed throughout the Jewish world. In the first half of the $17^{\text {th }}$ century a new type of masonry type synagogue building was developed: with a spacious interior divided into nine parts with the bimah placed between four massive pillars supporting a vaulted ceiling. Numerous wooden synagogues were built with impressive polychrome wall decoration and liturgical objects - unfortunately none of these has survived. Between the Great Wars in the twentieth century, Poland was home to the largest Jewish community in Europe, distinguished by its enormous cultural and intellectual vitality.

In Warsaw the Jewish community did not have a long tradition. Warsaw did not have the several hundred year old synagogues like Cracow, lacking both the old buildings and tradition of the great past. The city was never the headquarters of famous Jewish scholars. The oldest building belonging to Jews in Warsaw is dated 1811 (Jewish Synagogue at Prague District, 50/52 Targowa Street). The Jewish District began to grow rapidly in the last three decades of the $19^{\text {th }}$ century (Table 2 ). This coincided with the periods of economic boom in Warsaw, when industry developing and the technical infrastructure of the city was modernized. In 1897 there were already 219 thousand Jewish citizens living in the city (nearly $36 \%$ of total inhabitants). It should be emphasized that especially in the second half of the $19^{\text {th }}$ century the Jewish upper and middle class strongly influenced Warsaw's cultural life 
[Majewski 2019]. A number of rich, prominent families (as Kronenberg, Natanson, Toeplitz and Wawelberg) became 'rocks' of numerous educational and religious institutions. There were Jewish libraries, reading rooms, literary and music clubs, scientific societies, theatres and sports clubs. A well-developed network of charitable institutions allowed financing hospitals, old people's homes and orphanages. The most impressive synagogue in Warsaw was the Great Synagogue in Tłomackie Square. This synagogue was the only place in Warsaw to offer the special 'Reform' religious services in Polish language. This religious site was mainly visited by upper and middle class Jews as well as the Jewish intelligentsia. It was different in the Nożyk Synagogue, where not Polish, but Yiddish was spoken. The beautiful edifice of the Great Synagogue was designed by Leandro Marconi and completed in 1878. The synagogue was able to accommodate as much as 2,400 people and had a large hall, meeting rooms, an archive, a library, and a school. The Main Judaic Library was built next to the Great Synagogue at Tłomackie Street in 1936, designed in semi-modernism (eclectic) style. The Main Judaic Library was funded by donations of the Jewish population and municipal subsidies. Its designer was the architect Edward Zacharia Eber (1880-1939) [Drozdowski, Sołtan, Zahorski 2017; Majewski 2019; Piechotka M., Piechotka K. 2004b]. The Main Judaic Library building suffered major damage during the war, but was restored and re-opened in 1947. Today it houses the Jewish Historical Institute in Poland (in Polish: Żydowski Instytut Historyczny), which mission is to collect and promote the cultural achievements of Jews. Its archives contain a large collection of materials and documents relating to Jewish history in Poland. The Jewish Historical Institute in Poland was funded by the state in 1947. It acts under the auspices of the Polish Academy of Sciences. The Institute's library owns more than 60,000 volumes of literature and old manuscripts, from as early as the $10^{\text {th }}$ century. It includes also the Dr. Emanuel Ringelblum's Underground Archives (Figs. 12, 13) [jih.pl 2020].

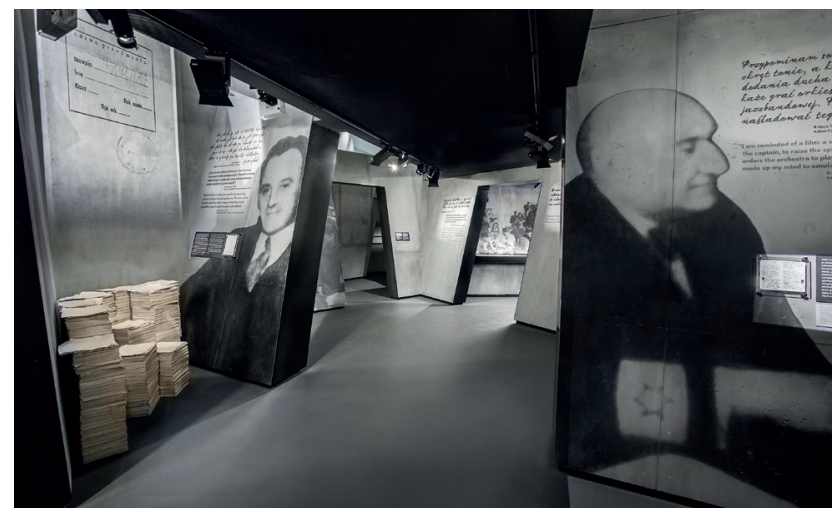

Fig. 12. The interior of the E. Ringelblum archive exhibition at the Polin Museum, Warsaw

Photo: M. Starowieyska, D. Golik, 2020, GNU Free Documentation

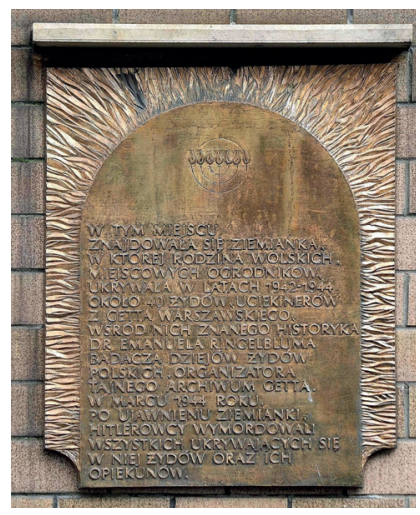

Fig. 13. A plaque in memory of the Ghetto inhabitants murdered by the Nazis, including E. Ringelblum, at Grójecka Street in Warsaw

Photo: A. Grycuk, 2014, GNU Free Documentation 
Before the World War II, Warsaw had one of the greatest numbers of Jewish inhabitants in Poland (in 1937 - about 350 000, nearly 38\% out of the city inhabitants). Warsaw was this time 'the Yiddish language capital of the world' and the historic Jewish quarter occupied nearly $1 / 5$ of the city area. It was commonly called 'the Northern District' or simply 'Nalewki'. Jews were able to settle in all parts of the city, but often they chose the northern district, the historic area of ghetto founded during partition of Poland, the Russia rules in the $19^{\text {th }}$ century. However, more assimilated Jews settled in other parts of the city, including the elegant city centre. The importance of Warsaw increased after Poland regained independence in 1918 and this time Warsaw was the cultural Jewish diaspora capital in Europe. There were numerous writers, poets and journalists writing in Yiddish. In some streets of the Northern District (Nalewki) and of Prague - one could have lived for years speaking only in Hebrew [Majewski 2019].

Although the Jewish heritage was almost annihilated by the Nazis in 1939-1944, when almost all of central Warsaw became a field of rubble, there are still several valuable traces of their material culture and history [Drozdowski, Sołtan, Zahorski 2017; Majewski 2019]. Despite the unprecedented suffering, many witnesses of the Jewish heritage in Warsaw have survived: synagogues, cemeteries and public buildings as: Monument to the Warsaw Ghetto Heroes by Nathan Rappaport, a remaining part of the Ghetto Wall (the largest of the Jewish ghettos established by Nazi Germany in the General Government during the Holocaust in World War II), Umschlagplatz Memorial, Nożyk Synagogue, the Od Jewish Cemetery (dating back to 1806, one of the largest in Poland, where many prominent Polish Jews were buried - as Zamenhof), the former Orphanage of Dr. Janusz Korczak, not to mention several $19^{\text {th }}$ century religious and public houses, which survived at Praga District (located at Jagiellońska and Targowa streets).

Before the outbreak of the World War II, there were as many as 400 Jewish houses of prayer in Warsaw. The Nożyk Synagogue is the only preserved pre-war synagogue. The Nożyk Synagogue was erected in 1902, designed by architect Karol Kozłowski in neo-Roman style with elements of Byzantine and Mauritian ornamentation. It was commissioned by Zelman Nożyk, a wealthy Jewish merchant and his wife Ryfka. The Nożyk Synagogue was renovated in the years 1977-1983. Today, there are services offered daily and on major Jewish holidays [Drozdowski, Sołtan, Zahorski 2017; Majewski 2019]. The oldest Jewish Cemetery was founded in 1799 at Bródno. It was severely destroyed during the World War II and in 1985 renovation works took place there.. The other Jewish Cemetery, at Okopowa Street, was founded at the beginning of the $19^{\text {th }}$ century. It is the largest Jewish cemetery in Warsaw, with as many as 250,000 people buried in 200,000 graves. One can find the gravestones of famous Jews, which include I.L. Peretz (writer), Esther Kamińska (actress) and Dr. Zamenhof (the creator of Esperanto language). At the Jewish Cemetery at Okopowa Street there is also a statue commemorating Janusz Korczak [Drozdowski, Sołtan, Zahorski 2017; Majewski 2019].

From the late $18^{\text {th }}$ century, the Jewish community in Praga Borough was concentrated at Szeroka and Petersburska streets (now Jagiellońska and Kłopotowska). A masonry synagogue was built there in 1836, designed by architect Josef Lessel. After the World War II, 
the building housed offices of the Central Jewish Committee in Poland. In 1961, although it was in good technical condition, the building was demolished despite an energetic Jewish protest. In the past, most of Warsaw's synagogues were small, prayer houses (or rooms) located in the courtyards or backyards of tenements. Recently one of such prayer houses was discovered in the old building at Targowa Street 50/52. It was built in 1811 and inside one can see fragments of wall paintings depicting the Western Wall, Rachel's Tomb and signs of the Zodiac remain. A much later Hebrew inscrip-

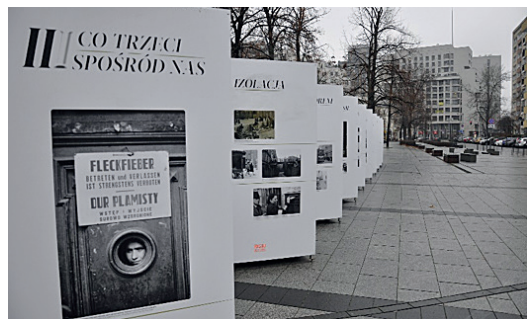

Fig. 14. The temporary outdoor exhibition about everyday life in Ghetto in 1943, the Grzybowski Square in Warsaw

Photo: A. Ostrowska-Tryzno, 2020 tion says that the paintings were financed by donations in 1934 [Majewski 2019] (Figs. 14, 15, 16).

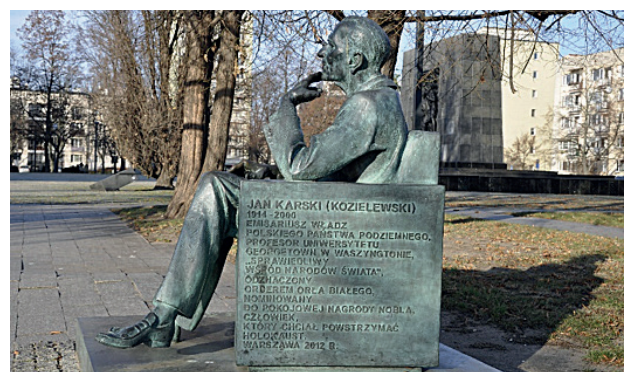

Fig. 15. The monument of Jan Karski, next to the Museum of the History of Polish Jews POLIN. Jan Karski was a Polish soldier and a courier during the World War II, who prepared reports about Germany's destruction of the Warsaw Ghetto and Nazi extermination camps in occupied Poland

Photo: A. Ostrowska-Tryzno, 2020

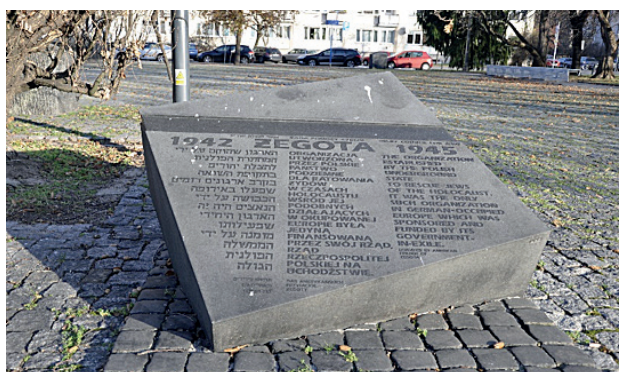

Fig. 16. The monument of Żegota, the organization established by the Polish underground state to rescue Jews from the Holocaust, next to the Museum of the History of Polish Jews POLIN in Warsaw

Photo: A. Ostrowska-Tryzno, 2020

As for several hundred years, Cracow, Lublin and Warsaw were the main centres of Jewish culture in Poland, today these three cities are frequently visited by domestic and international tourists, many coming from outside Europe but claiming their ancestral roots there. Therefore the 'Poland Jewish Tours', 'Warsaw Jewish Tours' or 'Warsaw-Cracow Jewish Tours' are seen as not only a chance to visit historical places and simply 'urban tourism' or popular 'city break' but also an opportunity to participate in religious traditions, taking part in cultural events (Jewish Festivals in Warsaw and Cracow) or historic commemorations such as Yom HaShoah, April $19^{\text {th }}$ Annual Ceremony of Warsaw Ghetto Uprising. Tourists appreciated possibility to meet other Jews and often took the opportunity to make some genealogical researches about family histories and connections. 
Today, a revival of Jewish culture in Warsaw is obvious. We can experience an incredible renaissance of interest shown to Jewish heritage (tangible and intangible) and tradition. The recently added event is the autumn literary festival, which celebrates the anniversary of Isaac Bashevis Singer's birthday or 'Próżna Street Festival' during annual spring 'museum soiree' in Warsaw. Tourists visiting Warsaw, during these events, could experience Jewish culture, be inspired by immense material and immaterial heritage. Our research showed that richness of Jewish heritage is also important for Warsaw residents. Popularity of the POLIN Museum (measured by number of visitors per annum - 350000 in 2016, 731420 in 2017) and the long queue of people wanting to visit the Nożyk Synagogue during 'museum soiree' each year in May are the best proofs [nimoz.pl, 2020]. Needless to say, learning about common culture and tradition is the best way to improve tolerance and understanding. Obviously in Warsaw, where there are so many sites connected with Jewish history and culture (sites of glory and tragedy) - we have this chance, knowing that tourism is built on people - to - people interactions and is an important vessel to promote culture and advanced cultural dialogue.

\section{Cultural tourism versus pandemic restrictions}

In both decades of the $21^{\text {st }}$ century, we have witnessed in Warsaw a steady increase in cultural tourism and its different forms (urban tourism, ethnic tourism). The development of international tourism has been closely related to the processes of globalization. The gradual liberalization of international trade, facilitation of foreign travel, the growing number of the middle class and its income have had a positive impact on the development of mass tourism - international and domestic. Last year, the UNWTO estimated international tourism at 1.5 billion people, forecasting an increase of $4 \%$ in 2020 as an obvious continuation of the trend that has been going on for a decade. Until a few months ago, the world of science and experts was concerned with the excessive growth of tourism in the future and a number of threats resulting from it, primarily for the environment. In the prepared by the UNWTO document "Decade of Action 2020-2030", 17 principles of sustainable tourism development in the next decade were formulated to counteract these negative phenomena.

In 2020, the outbreak of the COVID-19 pandemic has hit the tourism sector hard and travel restrictions still apply to us. Therefore, it is necessary to verify the old forecasts and prepare new recommendations for the directions of cultural tourism redevelopment. In June 2020, the UNWTO prepared the document 'Tourism Recovery Post COVID-19', which motto is: 'Stay home today. Travel tomorrow'. It distinguishes three pillars that determine the revival of tourism (at the global, national, regional and local levels): health, security and rebuilding consumer confidence. The UNWTO 'COVID-19 Tourism Recovery Technical Assistance Package' is focused on three main pillars: economic recovery, marketing and promotion, institutional strengthening and building resilience. At this critical stage The Tourism Recovery Package includes activities and strategies aimed for a long duration, for the medium terms 
and solutions, which might be implemented immediately (for example technical assistance programs, trainings) - depending on the specific situation and needs, tailor-made strategies can be offered [UNWTO 2020].

In the 'Travel Tomorrow and Share Culture' document recently prepared by the European Cultural Tourism Network (ECTN 2020), it was emphasized that cultural tourism will be the main driver of the revival of the tourism sector in Europe. It emphasized the following urgent actions that should be taken by institutions dealing with the development and promotion of cultural tourism:

- Constantly improved information and promotion, reaching the widest possible audience, searching for new recipients;

- Continuous implementation of innovative technologies, including an emphasis on virtual messages, expressed by slogan 'Today, online visitors to the museum, tomorrow, may appear in reality';

- Taking into account the necessity of many changes, including adjustments to existing commercial strategies, the scope and nature of tourist services offered; changes forced mainly by sanitary safety measures, perhaps a smaller share of older people in tourist traffic, a greater share of families with children, school trips and youth, individual tourists;

- Taking corrective actions together with government and local administration, non-governmental organizations, foundations, local cultural activists and tourism organizers.

In 2020, more than $80 \%$ museums around the world were closed down, but millions of tourists during the lockdown visited museums and sites on the UNESCO World Heritage List virtually [ECTN 2020, UNWTO 2020]. In 2020, when the museums were closed in Warsaw by law and government regulations, the high demand for virtual access to museums and heritage sites has been clearly seen. Despite the serious challenges, the cultural sector tried to create a new offer, attract new audiences, developed new attractions. In the Warsaw's POLIN Museum there were several offers of virtual visits, as 'POLIN Museum in Your Home' or 'Virtual Journey through the Core Exhibition', a special selection of exhibition tours, podcasts and audio-visual recordings, which could allow to visit museum on-line [polin.pl, 2020]. In 2020, the Praga Borough Museum in Warsaw (established in the former Jewish prayer house) offered virtual tours and free of charge virtual museum classes with the use of ZOOM platform, [muzeumwarszawy.pl]. As it is believed, these offers can spark interest in visiting the facility in real life. This expectation is expressed and summarized by the slogan of the spot prepared jointly by the UNWTO and CNN, currently in 2020, being broadcasted on many channels and in many countries - 'Plan your dream trips today, the departure will be tomorrow'.

To answer the pandemic challenges, in 2020 the Warsaw City Tours Agency, has offered, private, custom tours with the use of special transport: bikes or social - distance buses, securing sanitary safety (for example 'Private Jewish Warsaw Tour', 'Jewish Heritage in Warsaw'). Tourists can expect contactless payment, face masks available for customers and staff as required in public areas, sanitized transport vehicles with hand sanitation stands, social distancing enforced throughout all experience, regular temperature checks for staff [warsawcitytours.pl]. These are examples of already-developed some short-time strategies, the tourism 
industry sectors can individually adapt to recover projects and to better adjust their company to pandemics time restrictions as the immediate response to situation. However also other short, medium and long-term actions, developed by UNWTO in 2020 should be considered. They include the most detailed recommendations, as a proposal of counter shields at the hotel reception, as well as recommendations of general character: cooperating with the World Health Organization, information and data exchange between tourism sectors, innovative alliances, more sustainable future of cultural tourism, better coordination and information sharing (between government structures, locally and internationally), attracting wide audience (all social groups: children, youth, seniors).

Among the possible, immediate to be implemented strategies for the recovery of cultural tourism and adaptation to pandemic situation, simple and practical solutions may be helpful, such as: sanitary restrictions and cleaning protocols in museums and heritage buildings, health safety standards at restaurants and hotels (distance and reduction of occupancy rate, counter shields, hand washing, disinfection), change from personal interactions to the new technologies in order to limit contact and risk. In the medium and long-term, possibly further strategies might be helpful to improve sanitary safety and restore a confidence in travel, as for example advanced technologies, robots, artificial intelligence. All of this requires public-private collaboration to enable re-opening. However, these new procedures and challenges can increase prices and harm the business sustainability. Some experts believe in a full return to pre-crisis patterns and habits of travelling, although some predict that tourist might prefer a higher health safety standards also in the future, after lifting formal pandemic restrictions [Assaf, Scuderi 2020; Burni 2020; Iguman 2020; UNWTO 2020].

\section{Conclusion and discussion}

The broad definition of heritage implicates the complexity and diversity of heritage tourism. When visiting heritage sites, it seems that for tourists the great attraction is not only well preserved historic built environment, arts and cultural institutions activities, the heritage expressed not only by architecture - but also by diversity of traditional gastronomy, local dialects, traditional rituals, festivals, songs, jokes (presented by tourist guides). It seems that Warsaw Jewish heritage perfectly matches this expectation.

Recently there has been a revival of interests in Jewish heritage and many tourists (both domestic and international) want to explore Jewish culture and remaining landmarks of the past. Also due to numerous tourist groups visiting Warsaw, whose main purpose was to visit sites related to Jewish history and culture, so much has been done to restore Jewish monuments of architecture, often as a result of voluntary initiatives and financial support from different sources. It is to be emphasized that Jewish heritage in Warsaw might be a significant platform for shaping a better understanding of our 800-year history of sharing multicultural space. Such an experience seems to be especially important for the young generations of Polish, German, Russian and Israel students and school groups visiting our city. Moreover, 
Warsaw Jewish heritage is often part of popular round trips programme, organized by tour agencies in the Central Europe (Warsaw-Cracow-Budapest and Prague), showing even more broader perspective of Jewish presence in Europe and being so eagerly rediscovered today by the young generation, not only Europeans.

Although this paper was aimed to explore a wide range of issues related to the Warsaw's Jewish heritage and sustainable, safe tourism in the pandemic time, it cannot be argued that it covered all aspects of cultural tourism redevelopment as it was beyond our research scope. The intention was to highlight the implications of heritage tourism based on tangible and intangible Jewish culture and tradition preserved in Warsaw and to identify these substantial issues, which are relevant to heritage tourism redevelopment, during and after COVID-19 pandemic, in the short, medium and long-term perspective. Above all, important question arises, how we could plan today the cultural tourism development and redevelopment after the pandemic crisis. In the past, planning in details was a common practice, now we are aware of the fact, after what we have experienced in 2020, that many factors are unpredictable and planning is difficult - if not impossible. The only answer, as it seems - however of only general character, is flexibility, readiness for changes and quick adapting to the new circumstances, even necessity for improvisation to certain limits. Creativity, imagination, innovations and new technologies might be a great help with shaping the new offer of cultural tourism, securing sanitary restrictions and providing attractions. Therefore, it is necessary to verify the old forecasts and prepare new recommendations for the directions of cultural tourism redevelopment. It is to be underlined that planning heritage tourism redevelopment, requires solution of several problems, such as demands for sanitary safe hotels, restaurants, retail, public transport, museums and heritage sites. Bearing these in mind, it will be difficult to formulate general solutions and possibly each town and each heritage site must be individually evaluated.

Clearly, there has been a revival of interests in Jewish heritage and many tourists (both domestic and international) want to explore Jewish culture and remaining landmarks of the past in Warsaw and other sites in Poland. Now, as it seems, it is also possible, despite pandemic time travelling restrictions, however new actions and policy are required to secure sanitary recommendations. In order to rebuild consumer confidence and enable the recovery of cultural tourism, important could be: new travelling organization, law regulations, health safety restrictions (sightseeing as it is offered now by the Warsaw City Tours Agency), advanced technologies (virtual tours in the museums and heritage sites) and activities limited only to these which can take place outdoors.

However, to make it possible, the government's actions to support these strategies might be crucial: the tourism industry (hotels, restaurants, transport, travel agencies) and cultural institutions (museums, heritage sites) need credible measures focused on: interest-free loans, guaranteed loans, non-refundable subsidies, funds to develop marketing, strengthing the cultural identity, free webinars and trainings, helping to adapt and implement new technologies (audio-video tours), supporting and assistance in creating intensive promotion and branding of these destinations, which might be, despite pandemic restrictions, a strong attraction for 
cultural tourists. It should be noted that the revival of cultural tourism requires a strong support at national and international level, technical assistance programs through the relevant international institutions as the United Nation World Tourist Organization (UNWTO), the World Health Organization (WHO), the European Cultural Tourism Network (ECTN) and the United Nation Education Social and Cultural Organization (UNESCO).

According to experts, a year of break in tourism will significantly strengthen the appetite for sightseeing and traveling [ECTN 2020; UNWTO 2020]. However, there will probably be different conditions for travel, rest and sightseeing and perhaps a different type of tourist will dominate (possibly domestic rather than international, less seniors and more youth and children). Will it be a tourist interested in the 'Sun Sand Sea' profile, or rather in the cultural tourism - expressed by 'Education Entertainment Experience', or maybe a combination of both? It depends on pandemic situation but also on marketing, promotion and customer confidence - and it is possible to take care of it now, skillfully controlling the information and promotional message, treating the year 2020 as sacrificed for learning, gaining new skills, looking for inspiration, opportunities for changes in the company and the profile of tourist services. The UNWTO website hosts daily remote seminars, lectures and webinars devoted to this issue [UNWTO 2020].

Table 1. Museum of the History of Polish Jews POLIN in Warsaw - the frequency of visitors in comparison to leading Warsaw's museums

\begin{tabular}{|c|c|c|}
\hline Position & Museum & $\begin{array}{c}\text { Number of visitors / per } \\
\text { year (2017) }\end{array}$ \\
\hline 1 & $\begin{array}{l}\text { Museum of King Jan III's } \\
\text { Palace at Wilanów }\end{array}$ & $\begin{array}{l}3279889 \text { (visitors in the } \\
\text { historic palace gardens are } \\
\text { included, as entrance is } \\
\text { charged and statistic data } \\
\text { available) }\end{array}$ \\
\hline 2 & $\begin{array}{l}\text { Museum of the History of } \\
\text { Polish Jews in Warsaw }\end{array}$ & 731420 \\
\hline 3 & $\begin{array}{l}\text { The Royal Łazienki } \\
\text { Museum in Warsaw }\end{array}$ & $\begin{array}{l}728600 \text { (visitors in the } \\
\text { historic palace gardens are } \\
\text { not included, as entrance is } \\
\text { free of charge and statistic } \\
\text { data not available) }\end{array}$ \\
\hline 4 & $\begin{array}{l}\text { The National Museum in } \\
\text { Warsaw }\end{array}$ & 666032 \\
\hline
\end{tabular}

Source: based on the statistical data of National Institute of Museology and Collection, [www.nimoz.pl 2021] 
Table 2. Inhabitants in Warsaw in the years 1864-1938 (total number and Jews)

\begin{tabular}{|c|c|c|c|c|c|c|c|}
\hline Nationality & 1864 & 1882 & 1892 & 1897 & 1901 & 1921 & 1938 \\
\hline Total & 222906 & 382964 & 490417 & 421569 & 711988 & 936713 & 1265372 \\
\hline Jews & 72776 & 127917 & 163232 & 185077 & 254712 & 310334 & 368394 \\
\hline
\end{tabular}

Source: Drozdowski, Sołtan, Zahorski, 2017, Historia Warszawy (History of Warsaw), Wydawnictwo Bellona. Note: in the 2011, on the base of the National Public Assessments in Poland, as much as 7353 respondents declared to be Jews [www.stat.gov.pl 2021]

\section{References}

Assaf A., Scuderi R., 2020, 'COVID - 19 and the recovery of the tourism industry, Tourism Economics, 26, 5, pp. 731-733; DOI: doi.org/10.1177/1354816620933712.

Burni F. (ed.), 2020, Tourism facing a pandemic: from crisis to recovery, University of Bergamo; Bergamo, DOI: 10.6092/978-88-97253-04-4.

Central Statistical Office GUS in Warsaw, 2021, Statistical Yearbook of Warsaw, GUS, Warsaw.

Dallen J.T., Boyd T.S., 2003, Heritage Tourism, $1^{\text {st }}$ Edition, Prentice Hall, NJ, USA.

Drozdowski M., Sołtan M., Zahorski A., 2017, Historia Warszawy, Wydawnictwo Bellona, Warszawa.

The European Economic and Social Committee, 2005a, Contribution of tourism to the socio-economic recovery of areas in decline. Declaration of Cordoba, $1^{\text {st }}$ Edition, EESC Pamphlet Series, Brussels.

The European Economic and Social Committee, 2005b, Tourism policy in the enlarged European Union. Katowice Declaration, $1^{\text {st }}$ Edition, EESC Pamphlet Series, Brussels.

Finn M., Elliott-White M., Walton M., 2000, Tourism and Leisure Research Methods. Data collection, analysis, evaluation and interpretation, Pearson-Longman, Harlow.

Hall C. M., 2000, Tourism Planning, Policies, Process and Relationships, Prentice Hall, NY.

Herman K., Drozda Ł., 2021, Green Infrastructure in the Time of Social Distancing: Urban Policy and the Tactical Pandemic Urbanism, Sustainability, 13, 4, pp. 16-31, DOI: 10.3390/su13041632 (Sustainable Special Issue: Landscapes in the Time of Social Distancing: Pandemic and Design of the Urban Environment, February 2021).

Iguman S., 2020, If visitors will not go to Heritage, Heritage must go to visitors. Digitalisation Heritage in time of Corona [in:] F. Burni (ed.), Tourism facing a pandemic: from crisis to recovery, University of Bergamo; pp. 165-175; DOI: 10.6092/978-88-97253-04-4.

Inskeep E., 1991, Tourism Planning: an Integrated and Sustainable Development Approach, John Wiley \& Sons, Inc., NY. 
Law C.M., 1996, Urban Tourism. Attracting visitors to large cities, $3^{\text {rd }}$ Edition, Mansell, London. Loyke L., Edmunds J., 2007, Key Concepts in Tourism, $1^{\text {st }}$ Edition, Palgrave-Macmillan, NY. Majewski J.S., 2019, The Never Reconstructed Warsaw. Jewish Muranów and its surroundings, Agora SA, Warsaw.

Piechotka M., Piechotka K., 2004a, Oppidum Judaeorum, Krupski i Ska, Poznań.

Piechotka M., Piechotka K., 2004b, Heaven's Gates - Wooden Synagogues in the Territories of the Former Polish-Lithuanian Commonwealth, Krupski i Ska, Poznań.

Polin Museum of the History of Polish Jews, 2019, Annual Report 2018, Warsaw.

Sigala M., Leslie D., 2006, The International Cultural Tourism: Management, implication and cases, $2^{\text {nd }}$ Edition, Elsevier, (UK).

Smith M.K. , 2006, Issues on Cultural Tourism Studies, $2^{\text {nd }}$ Edition, Rutledge, London.

The Warsaw Capital City Office, 1993, Warsaw Physical Development, $1^{\text {st }}$ Edition, Warsaw Chapter of Polish Planners Society, Warsaw.

Williams S., 2003, Tourism and Recreation, $1^{\text {st }}$ Edition, Prentice Hall, Harlow.

The World Tourism Organization UNWTO, 2005, City Tourism and Culture, UNWTO, Madrid.

\section{Internet resources}

www.ectn.org (European Cultural Tourism Network), [access in 2020]

www.jih.pl (Żydowski Instytut Historyczny), [access in 2020]

www.muzeumwarszawy.pl (Praga Borough Museum, branch of Warsaw Museum), [access in 2019, 2020]

www.nimoz.pl (Narodowy Instytut Muzealnictwa i Ochrony Zbiorów), [access in 2020]

www. polin.pl (Museum Polin in Warsaw, Poland), [access in 2019, 2020]

www. stat.gov.pl (Central Statistical Office GUS, Poland), [access in 2019, 2020]

www.unesco.org (United Nations Education and Science Organization), [access in 2020]

www.um.warszawa.pl (City of Warsaw), [access in 2021]

www.unwto.org (UN World Tourism Organization), [access in 2020]

www.warsawcitytours.pl (Warsaw City Tours Agency), [access in 2020] 


\section{Dziedzictwo wielokulturowości jako podstawa zrównoważonego rozwoju turystyki miejskiej w Warszawie - czas pandemii COVID-19}

\section{STRESZCZENIE}

Wprowadzenie: znaczenie wielokulturowości dla rozwoju turystyki, podkreślane konsekwentnie w literaturze przedmiotu, świadczy o popularności tej formy turystyki. Polska historycznie była krajem przejściowym między Wschodem a Zachodem, krajem, w którym obok siebie istniały różne kultury: niemiecka, żydowska, polska i rosyjska. Polska przez wieki była miejscem spotkań różnych religii i kultur, a dzisiejszy krajobraz wciąż na to wskazuje. Katastrofa drugiej wojny światowej przyniosła unicestwienie społeczeństwa wielokulturowego i stworzyła niespotykaną dotąd w naszej historii jednorodność.

Dziedzictwo żydowskie i miejska turystyka kulturowa: w swojej prawie 2000-letniej diasporze Żydzi byli obecni w Polsce od ośmiuset lat: od wczesnego średniowiecza do Holokaustu, Zagłady w okresie drugiej wojny światowej. Od innych grup społecznych Żydów wyróżniała religia, język, zwyczaje, sztuka i architektura. W okresie międzywojennym XX w. Polska była domem największej społeczności żydowskiej w Europie, wyróżniającej się ogromną żywotnością kulturową i intelektualną. Zachowane ślady (materialne i niematerialne) dziedzictwa żydowskiego w Warszawie stały się podstawą rozwoju turystyki kulturowej.

Czas pandemii a turystyka miejska: wybuch pandemii COVID-19 silnie uderzył w sektor turystyczny: obowiązują ograniczenia w podróżowaniu, zamknięte są muzea. Dlatego konieczna jest weryfikacja prognoz i przygotowanie nowych rekomendacji dla kierunków turystyki kulturowej w czasie pandemii i w okresie po jej zakończeniu.

Podsumowanie i wnioski: zainteresowanie dziedzictwem żydowskim jest silne od kilku dekad i wielu turystów, zarówno krajowych, jak i zagranicznych chce zgłębiać kulturę żydowską i przetrwałe zabytki przeszłości. Pomimo ograniczeń sanitarnych nawet w czasie pandemii jest to możliwe, jednak potrzebne jest wypracowanie racjonalnych procedur, aby zarówno zapewnić reżim sanitarny, jak i odbudować zaufanie konsumentów.

Słowa kluczowe: dziedzictwo kulturowe Żydów, turystyka miejska, pandemia COVID-19 
Anna Ostrowska-Tryzno - PhD in physical culture, works at the Faculty of Physical Education at the Józef Piłsudski University of Physical Education in Warsaw. She specializes in sustainable urban development and responsible business tourism. She is currently focusing her research activity on issues related to outdoor sports and recreation infrastructure in cities, accessible for children, youth, the elderly and people with disabilities.

e-mail:anna.tryzno@awf.edu.pl

ORCID:0000-0002-2539-7900

Anna Ostrowska-Tryzno - dr nauk o kulturze fizycznej, adiunkt na Wydziale Wychowania Fizycznego AWF w Warszawie. Specjalizuje się w problematyce zrównoważonego rozwoju miast oraz odpowiedzialnej turystyce biznesowej. Aktualnie koncentruje swoją aktywność badawczq̨ na zagadnieniach dotyczących plenerowej infrastruktury sportowo-rekreacyjnej w miastach, dostępnej dla dzieci i młodzieży, osób starszych oraz osób z niepełnosprawnościami.

e-mail: anna.tryzno@awf.edu.pl

ORCID: 0000-0002-2539-7900

Anna Pawlikowska-Piechotka, Prof, PhD Eng, DSc, Arch - architect and urban planner, between 2004-2014 a visiting professor at University College Birmingham (United Kingdom), Charles University of Prague (Czech Republic), University of Lahti (Finland), University of Saragossa (Spain), University of Evora (Portugal), University of Viseu (Portugal), Holar University (Iceland). Focuses in her research on the usage of cultural heritage for sustainable tourism and responsible planning for tourism, sport and recreation. Participated in several international research projects (Germany, Sweden, Holland, UK, Poland, Turkey). Author of over two hundred scientific publications, including several monographs, papers published in English, German, Polish and Serbian. Co-author of several architectural and urban plans of recreation and tourist space (commissioned in Poland, Germany, Nigeria and Libya) and utility models of recreation facilities for disabled - formally registered in the Polish Patent Office.

Contact: the Józef Piłsudski University of Physical Education in Warsaw;

e-mail:anna.piechotka@gmail.com

ORCID: 0000000304290327

Anna Pawlikowska-Piechotka, prof. dr hab. inż. arch. - architekt i urbanista, w latach 2004-2014 profesor wizytujący na University College Birmingham (Wielka Brytania), Charles University of Prague (Czechy), University of Lahti (Finlandia), University of Saragossa (Hiszpania), University of Evora (Portugalia), University of Viseau (Portugalia), Holar University (Islandia). W swoich badaniach koncentruje się na wykorzystaniu dziedzictwa kulturowego dla zrównoważonego rozwoju turystyki i odpowiedzialnego planowania przestrzeni turystyki, sportu i rekreacji. Uczestniczyła w kilku międzynarodowych projektach badawczych (Niemcy, Szwecja, Holandia, Wielka Brytania, Polska, Turcja); jest autorem ponad dwustu publikacji naukowych, w tym kilku monografii, tekstów opublikowanych w języku angielskim, niemieckim, polskim i serbskim; współautor kilkudziesięciu planów architektonicznych i urbanistycznych (zrealizowanych w Polsce, Niemczech, Nigerii i Libii) oraz wzorów użytkowych obiektów rekreacyjnych dla osób niepełnosprawnych - formalnie zarejestrowanych w Urzędzie Patentowym RP.

Kontakt: Akademia Wychowania Fizycznego Józefa Piłsudskiego w Warszawie;

e-mail:anna.piechotka@gmail.com

ORCID:0000 000304290327 